Canadian University Music Review

Revue de musique des universités canadiennes

\title{
Tomás Luis de Victoria's Second Thoughts: A Reappraisal
}

\section{Eugene Casjen Cramer}

Numéro 6, 1985

URI : https://id.erudit.org/iderudit/1014039ar

DOI : https://doi.org/10.7202/1014039ar

Aller au sommaire du numéro

Éditeur(s)

Canadian University Music Society / Société de musique des universités

canadiennes

ISSN

0710-0353 (imprimé)

2291-2436 (numérique)

Découvrir la revue

Citer cet article

Cramer, E. C. (1985). Tomás Luis de Victoria's Second Thoughts: A Reappraisal. Canadian University Music Review / Revue de musique des universités

canadiennes, (6), 256-283. https://doi.org/10.7202/1014039ar

(c) Canadian University Music Society / Société de musique des universités canadiennes, 1985
Ce document est protégé par la loi sur le droit d'auteur. L'utilisation des services d'Érudit (y compris la reproduction) est assujettie à sa politique d'utilisation que vous pouvez consulter en ligne.

https://apropos.erudit.org/fr/usagers/politique-dutilisation/ 


\title{
TOMÁS LUIS DE VICTORIA'S SECOND THOUGHTS: A REAPPRAISAL
}

\author{
Eugene Casjen Cramer
}

Tomás Luis de Victoria stands apart, in a number of significant ways, from the majority of his contemporaries both great and small. For one, the amount of music which he apparently composed is relatively small. For another, he appears to have written not one note of either secular or instrumental music - his commitment to sacred music was total. For yet another, most of his music was published during his lifetime. Moreover, most of his early works were reprinted at least once and some as many as five times - also during his lifetime. Further, the second printing, and occasionally also a subsequent printing of a large percentage of his works, often differs in significant ways from its original form. Finally, several of his works have come down to us in both a manuscript and a printed source which do not always exactly concord.

Of these remarkable dissimilarities it is the last two that are at once the least well known and the most provocative. Primary among the questions which the presence of these differences cum revisions raises is the obvious: "Who is responsible?" Was it Victoria or someone else - a printer, a well-meaning colleague, a pupil perhaps - who made them? While it is conceivable that minor changes such as the deletion of certain accidentals in some of the later printed editions may have been made or forced upon him by his printers, it is extremely unlikely that a colleague or a pupil, if indeed he had any, would have dared to alter his work at least not without his knowledge and approval. Furthermore, if the title pages of the 1583 Roman and 1603 Venetian imprints of his motets, which proclaim that the contents were noviter recognita, are to be believed, Victoria alone was responsible for the vast 
majority of the revisions found in the extant printed sources of his works.

Assuming, then, that Victoria did make the revisions himself, the next question is: "Why were they made?" Was it to bring his works in line with the taste of a particular group? Was it to update his early efforts in order to reflect either his improved technique or present style, or both? Or was he, like Anton Bruckner, simply an inveterate tinkerer?

With these questions in mind Victoria's printed revisions, all of which were made between 1583 and 1600 to works which were either published or presumed to have been written by 1581 , will now be examined.

As it turns out, some of Victoria's revisions or second thoughts do not tell us very much about either his technical or stylistic development because the change is either one of the omission or addition of entire pieces of music rather than one of recomposition or minor alteration of a particular passage. For example, when Victoria reprinted his Missa Pro Defunctis in 1592, originally published in 1583 , he included two new pieces - the responsories "Peccantem me" and "Credo quod Redemptor." And when he came to publish his set of Lamentations in the Officium Hebdomadae Sanctae in 1585 he omitted eleven of the pieces which were present in the version found in Cappella Sistina Ms. 186 and also added six new ones. The published version of the Missa Quarti Toni (1592) omits several fragments of music which are in one of the manuscript sources. One can only guess as to why changes of this kind were made. The reasoning ranges from musical to liturgical, but it may also have been sheer whimsy. The evidence one way or the other is inconclusive.

\section{Dissonance Treatment}

The changes Victoria made in the handling of certain dissonances, on the other hand, are enlightening. Victoria's apparent preoccupation with the type of dissonance known as the escape note, that is, a conjunctly introduced dissonant note left by a leap, usually upward and usually of a fourth, is the most informative in this regard.

In his time-honored study of Palestrina, Knud Jeppesen devoted several pages to a discussion of this dissonance, noting that the escape note is found frequently in the works of Josquin, Obrecht, and Isaac, whereas Palestrina made only "sparing use" of it and "mostly in his earlier works" (Jeppesen 1970: 202). Thus, the 
obvious conclusion is that the escape note is a characteristic of the early sixteenth-century Netherlandish musical style and not a characteristic of the later Roman school of composition and, therefore, its presence or absence can be construed as a stylistic watermark.

In a recent study of the four-voiced motets of Crecquillon, $\mathrm{H}$. Lowen Marshall pointed out that fifty-three instances of escape notes are found in twenty-nine of the fifty-four motets studied (see Marshall 1970: 95). Inasmuch as Crecquillon is a Netherlandish composer of the generation after Josquin, Marshall's findings both corroborate those of Jeppesen and extend the chronological limits of the use of this type of dissonance to at least the mid century.

In his dissertation on the contrapuntal and harmonic style of Victoria, James Arthur Kriewald listed 126 examples of the escape note in the music of this Spanish master (see Kriewald 1968: 255-62). On the basis of this amazingly large number of examples in Victoria's music, Kriewald concluded that it was "an essential element in the style of Victoria" (ibid.: 26). Assuming that he is correct in this assessment, his conclusion raises several questions. First, because Victoria is a late sixteenth/early seventeenthcentury composer, can one extend the chronological limits of the use of this dissonance to about 1600 and/or say with confidence that the escape note is a stylistic determinant in the chronological sense? Second, since Victoria has long been considered by many to be a member of the Roman school, is his use of the escape note a feature of his style that sets him apart from Palestrina, that is to say, is his use of the escape note an interesting archaism in an otherwise thoroughly modern style of polyphony, or does his extensive use of this dissonance mark his lineage to the polyphonic style of the North rather than that of Rome?

Before commenting briefly on these questions, it should be pointed out that statistics such as those which Kriewald gives, while necessary for ongoing research into musical style, do not tell the entire story. For example, a careful analysis of Kriewald's list of escape notes in the works of Victoria shows that thirty-seven of them are in works that were published in 1572, thirty-three in works from 1576, and thirty-seven more in the two publications of 1581. Thus, all but fifteen of the escape notes in Victoria's music are to be found in pieces that were written before 1581. On the basis of this perspective, Kriewald's conclusion should be amended to say that there is, in the music of Victoria, an "early" and a "late" style, that is, a pre-1581 and a post-1581 style. 
Incidentally, this view accords with the theory expressed by Robert Stevenson in his monumental study of Spanish polyphony in the sixteenth century that Victoria's art did not remain static, but steadily evolved and that two of the features of this maturation are the modernization of certain passages in the later reprints of his works and the presence of technical features in the late works that are not to be found in the early ones (see Stevenson 1961: 377).

However, even though the facts seem to support it, is this a proper conclusion? Let us look for a moment at Victoria's Lamentations for additional evidence. In the version in Cappella Sistina Ms. 186, which dates from ca. 1565 and ca. 1575 (see Cramer 1982: 51-53), there are six instances of the escape note. In the published version of 1585 there are none. The complete obliteration of the escape note in this version would seem to corroborate the conclusion that the change has chronological relevance. And yet, closer scrutiny shows that only three of the escape notes are in fact replaced by passing notes, that is, are modernized (perhaps one could even say Romanized). Two of the escape notes in Cappella Sistina Ms. 186 occur in passages that were completely rewritten for the 1585 version and one in a passage that was omitted entirely. Thus, in half of the cases it was not necessarily a desire to be rid of the escape note that prompted the change, but was, possibly, a basic dissatisfaction with the passage itself.

A manuscript version of the motet "Quam pulchri sunt" in the Biblioteca Musical de la Diputacio de Barcelona is also relevant to this discussion (see Stevenson 1961: 446). In measure seventy-six of the cantus of the Barcelona version there is an escape note where the printed version of 1572 has none. If we assume that the substitution of a passing tone for an escape note is an example of Victoria's later style, then we must conclude that this manuscript is earlier than 1572, a very questionable assumption at best, and also that Victoria's late style began as early as 1572 , which is patently impossible since Victoria was probably still in his early twenties. Because this source appears on this basis to be later than the print, and even if it were contemporary with it, the idea of the escape note as a stylistic determinant in the chronological sense is called into question. Moreover, if the absence of escape notes is indeed a feature of Victoria's late style, why did he not replace all of them in those compositions that were later reprinted?

As if this were not enough to indicate the folly of believing the 
escape note to be a stylistic feature in the chronological sense, there is the case of the Missa Salve regina of 1592, a Mass based on Victoria's eight-voiced "Salve regina" motet of 1576. On the one hand, we observe that in the mass Victoria omits the escape note present in measure eight of the motet when this passage appears in measure five of both the Gloria and the Agnus movements. On the other hand, we also see that in measure sixteen of the same Agnus, Victoria adds an escape note to a passage where there was none in the motet model, in measure 182. Furthermore, in the new pieces that Victoria published in Madrid in 1600 , one finds four escape notes.

There is an important conclusion to be drawn from this survey of Victoria's use of the escape note. His recourse to it in his later works and his retention of it in the later reprints of certain of his works shows that this type of dissonance is not a stylistic watermark in the chronological sense, but only in a more general stylistic sense. In short, on the basis of Victoria's use of the escape note, one probably should not speak of an early or late style or rely on it to date compositions or sources. One may, however, probably trace stylistic influences through its employment or its absence in a particular composer's compositions. When viewed from this perspective, Victoria's stylistic heritage is definitely that of the Netherlanders, Josquin in particular, and his total aversion to it in the Lamentations of the Officium Hebdomadae Sanctae of 1585 probably represents an attempt on his part to Romanize his style - an attempt that did not, however, achieve its presumed objective, that is, a spot for this work in the repertory of the Sistine Chapel. And it is reasonable to assume that he later had second thoughts on this matter because he seems to have realized that the Roman style, as exemplified in the sparing use of the escape note, was essentially foreign to both his early training and his musical disposition.

\section{Ornamentation}

Moving now to another of the major areas in which Victoria made changes in later printing of his works, we find that the Cappella Sistina Ms. 186 version of the Lamentations also contains five examples of a quasi fifteenth-century ornamented cadential figure, one of which is given in Example 1a. None of these was retained in the 1585 version of this work. In four of the cases, the decoration was simplified to a basic melodic line, as shown in Example 1b. The remaining appearance of this figure was 
suppressed by omitting from the printed version the entire piece of music in which it appears in the manuscript version. Because the figure is common in the 1572 motets, here too the evidence seems to indicate that the 1585 version of the Lamentations represents an attempt by Victoria to update or modernize his works. That this is not actually the case is borne out by the observation that this figure is used often in the Benedictus of the Missa Alma Redemptoris Mater (1600), a section of this work that differs from both of its models at this point by the inclusion of this ornamental figure, and by the fact that this figure also appears in the 1592 Missa Salve regina, in measure forty-two of the Kyrie, a passage only vaguely related to its 1576 model which, in any case, does not use this figure at this point.

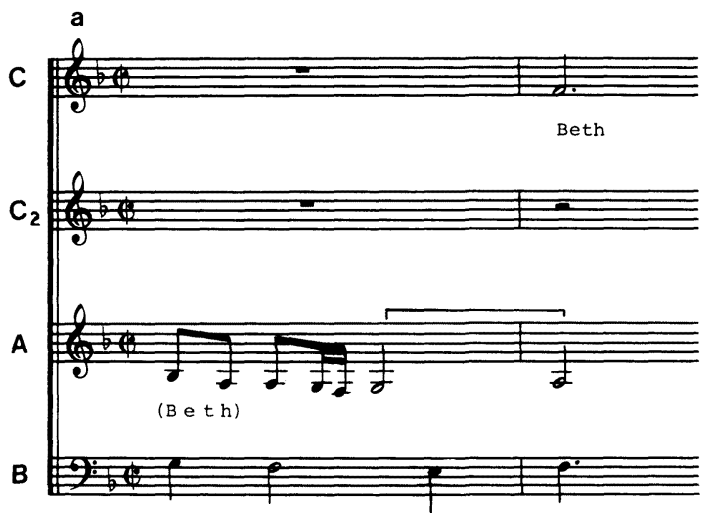

(B e $t h)$

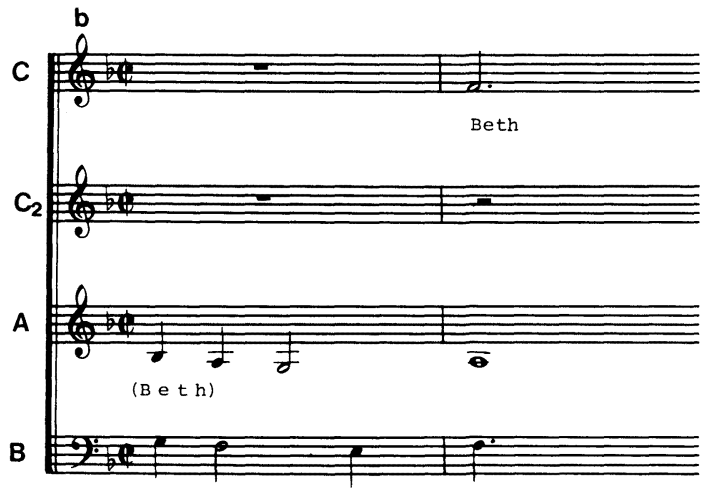

( $B \in t h)$

Extract from Lectio I of the Thursday Lamentations.

(a) Cappella Sistina Ms. 186 version,

(b) Officium Hebdomadae Sanctae version.

Example 1 
The difficulties of using this kind of change to demonstrate stylistic development and to date sources are incontrovertably shown in the manuscript version of the motet "Quam pulchri sunt" referred to earlier. On the one hand, this source includes the escape note, and on the other, the simplified form of the cadential figure under discussion. The two variants from the version published in 1572 pull in opposite directions. Both cannot be "early" characteristics.

In the 1585 version of the Lamentations Victoria supplied several melodies with embellishments of the type a late sixteenthcentury singer or instrumentalist might have added by following the suggestions given in some of the tutors of the period, such as Ganassi's Fontegara (Venice, 1535). One such passage is given in Example 2.

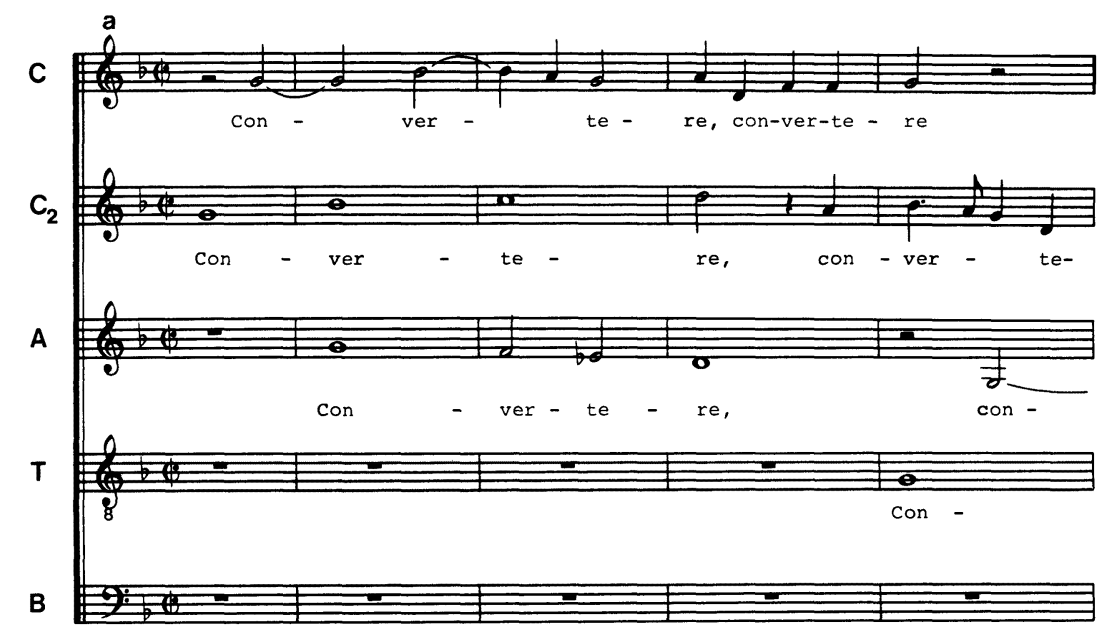




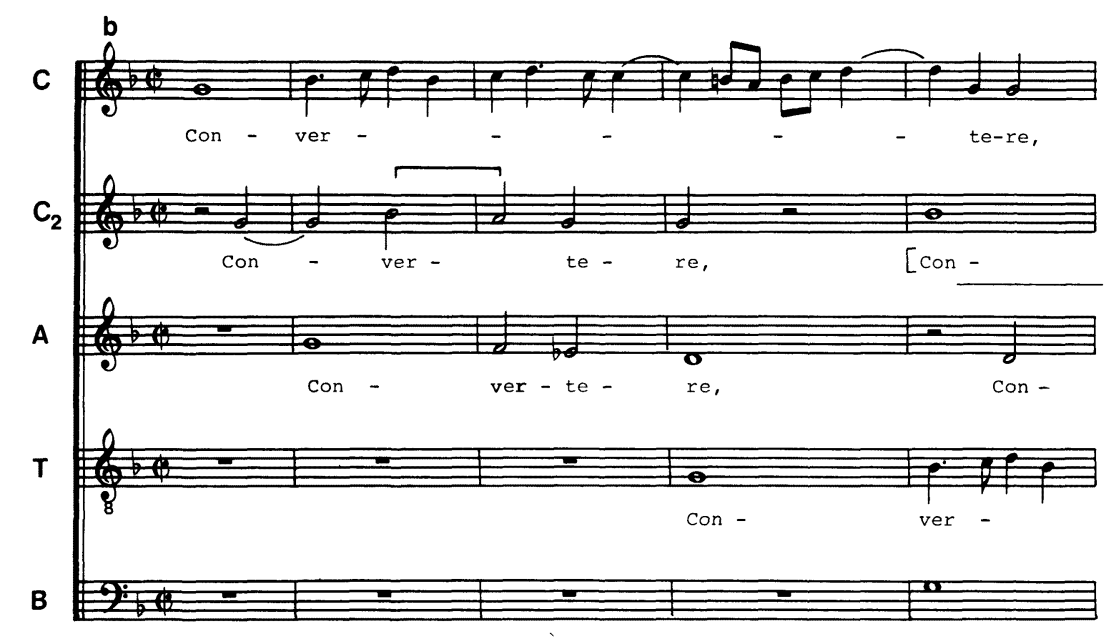

Con-

Extract from the conclusio a5 of Lectio II of the Lamentations for Thursday.

(a) Cappella Sistina Ms. 186, (b) Officium Hebdomadae Sanctae. Example 2

Although such examples are few in number and none of the others known to this author is as extensive as this one, the fact that they occur at all is proof that Victoria's music, and quite possibly the sacred music of the sixteenth century in general, was ornamented not only when it was performed da concerto, as the ornamentations given for the motet "Vadam et circuibo" in Bovicelli's Regole Passagi di Musica of 1594 show, but also when it was performed da chiesa. At the very least, it shows that Victoria approved of this practice because otherwise he would probably not have taken the time to embellish even one passage. It goes without saying that Victoria's ornamentation, as in Example 2, gives us an authoritative model for the embellishment of other melodic lines in Victoria's works, should the spirit move us to do so. It should also be noted that the addition of embellishments of this kind is a reversal of the simplification process observed earlier in regard to the changes he made in the same publication, and in the $1580 \mathrm{~s}$ in general, in the areas of dissonance treatment and cadential ornamentation, and, therefore, these changes cannot be construed to be the result of an attempt to appease a particular group of people, that is, the Romans.

If Victoria had been content to add ornamentation to the melodies in his Lamentations, we could conclude that he was 
attempting to show us the way he wished such things to be done in the $1580 \mathrm{~s}$ as opposed to the way that they had been done around 1565. But he was not content only to add. He left many similar melodies unornamented, and he deleted existing ornaments in others. In the passage given in Example 3, for example, Victoria deletes and transfers embellishments. Here, the figure in the penultimate measure of the cantus of the Cappella Sistina Ms 186 version has been moved to the tenor of the 1585 version and elaborated somewhat, leaving the cantus unadorned in the later version. And the related figure in the penultimate measure of the cantus secundus of the Cappella Sistina Ms. 186 version, as well as the ornamented 4-3 suspension in the final measure of this voice, has been dropped in the printed version.

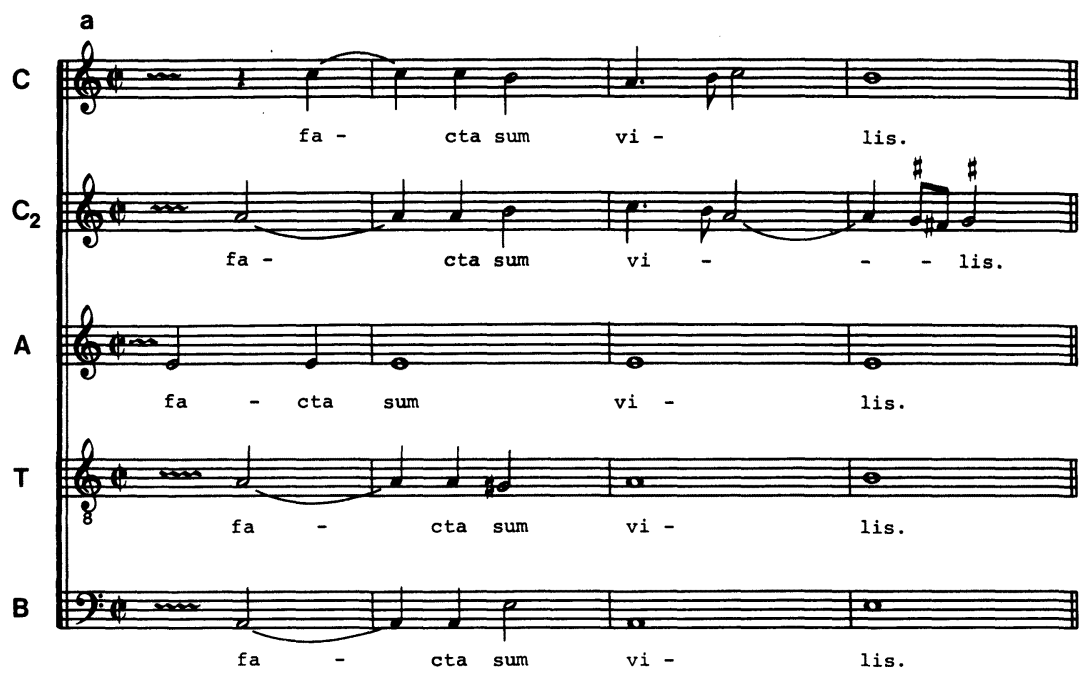




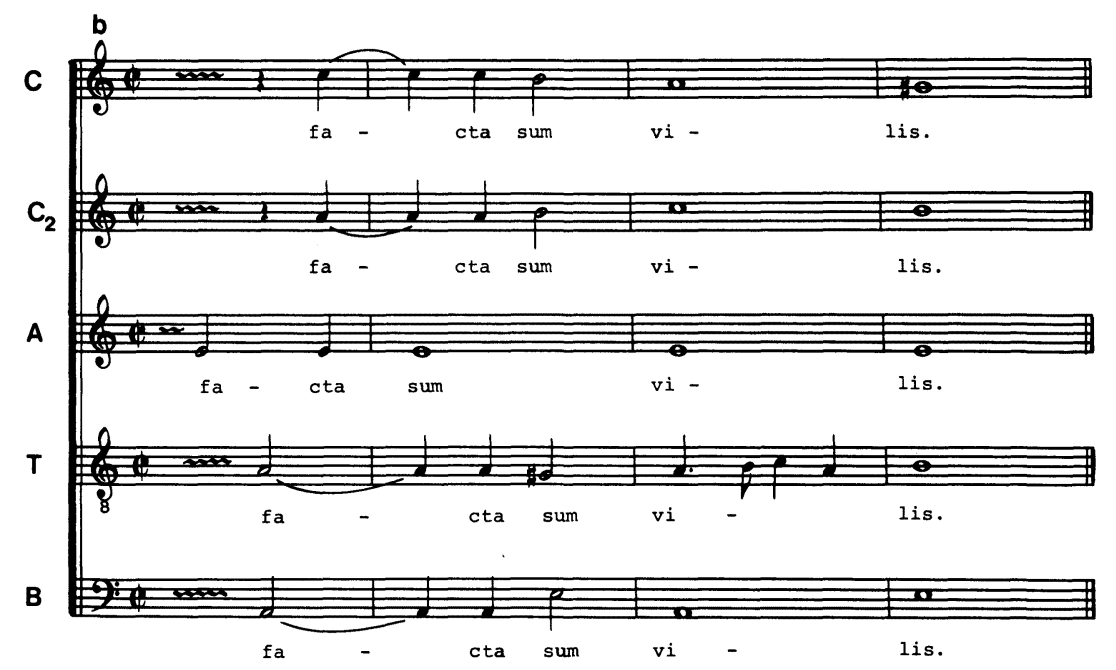

Extract from Lectio III of the Thursday Lamentations.

(a) Cappella Sistina Ms. 186, (b) Officium Hebdomadae Sanctae. Example 3

Even more characteristic of Victoria's inconsistency and seeming lack of direction in the area of melodic ornamentation are the numerous passages in the Lamentations in which a lower neighbor, or passing note, or anticipation has been added in close proximity to passages where ornamental figures like these have been deleted. As examples of this phenomenon we cite two passages in the Lessons for Good Friday, Examples 4 and 5 respectively. In the first passage, the version printed in the 1585 Officium Hebdomadae Sanctae is so replete with added passing tones and other embellishments that the earlier version is austere by comparison. The reverse, however, is true of the second passage. In it the passing notes in the cantus and tenor voices as well as the consonant anticipation which graced the cantus secundus of the early version do not appear in the Officium Hebdomadae Sanctae and in this case the later one is the more austere of the two. 

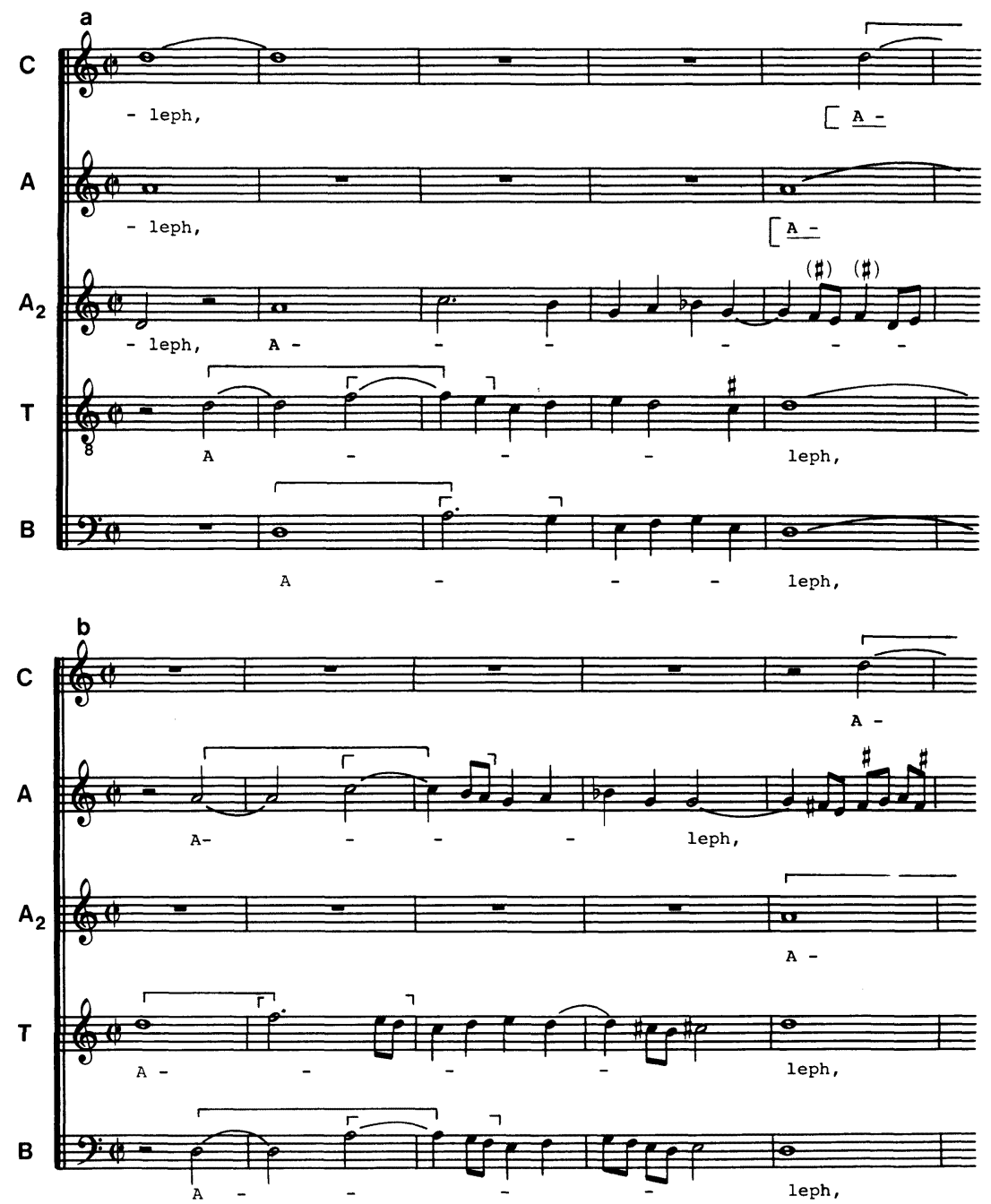

Extract from Lectio III of the Friday Lamentations.

(a) Cappella Sistina Ms. 186, (b) Officium Hebdomadae Sanctae. Example 4 

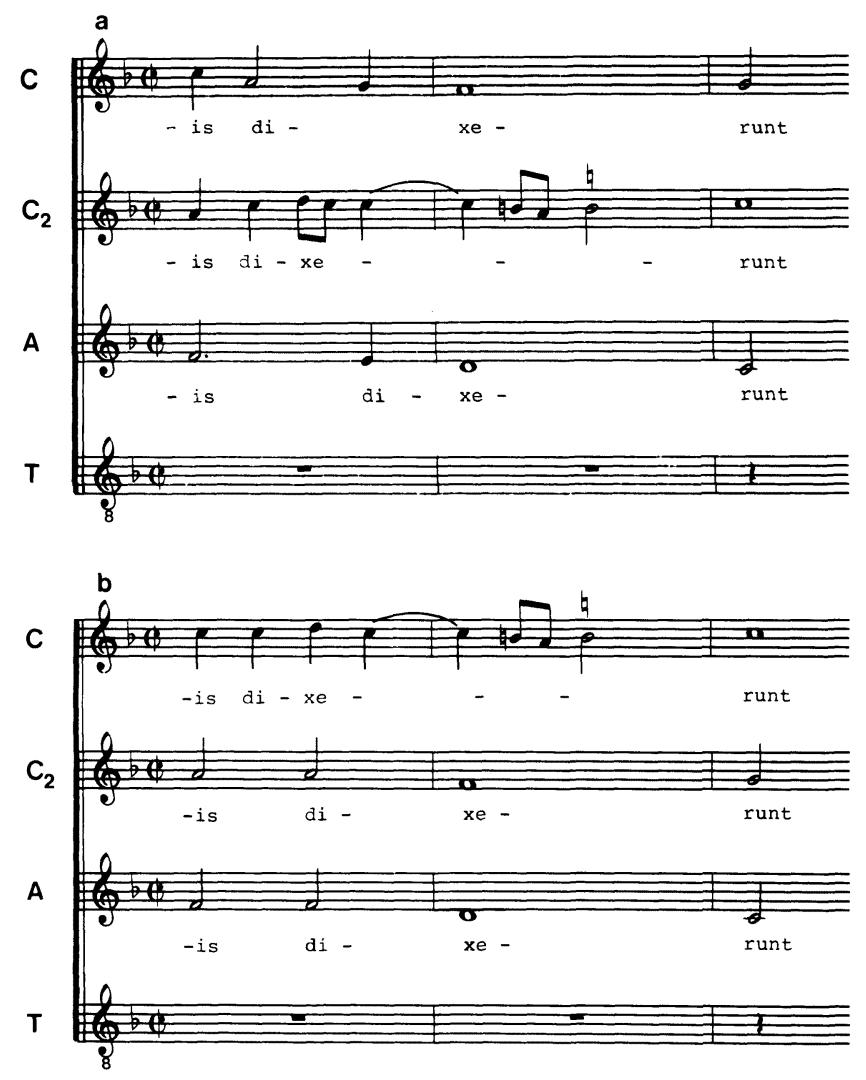

Extract from Lectio II of the Friday Lamentations.

(a) Cappella Sistina Ms. 186, (b) Officium Hebdomadae Sanctae. Example 5

The ornamental resolution of the 4-3 suspension is also an interesting example of Victoria's ambivalence in this area. In the passage given in Example 3, he dropped not only the ornamented resolution, but also, as was noted above, the $4-3$ suspension itself. A more common procedure, however, is the one shown in Example 6. This passage is one of the thirteen occasions in which only the suspension (here also with a consonant anticipation) is retained in the later version, that is to say, the ornamented resolutions found in Cappella Sistina Ms. 186 have been omitted. But we cannot be certain that these simplifications represented a deliberate change in style because there are several passages in which the ornamented resolution as such was retained in the Officium 
Hebdomadae Sanctae and even two occasions, one of which is given in Example 7, where Victoria chose not only to add a 4-3 suspension where one did not exist in the earlier version, but also to ornament it!

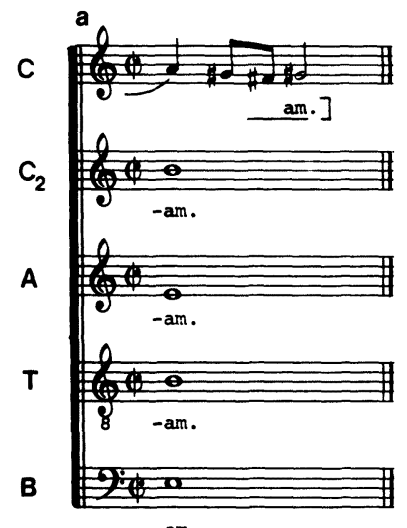

-am.

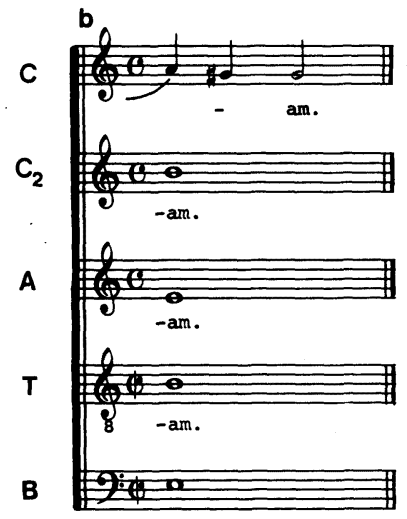

$-a m$.

Extract from Lection III of the Thursday Lamentations.

(a) Cappella Sistina Ms. 186, (b) Officium Hebdomadae Sanctae.

Example 6 

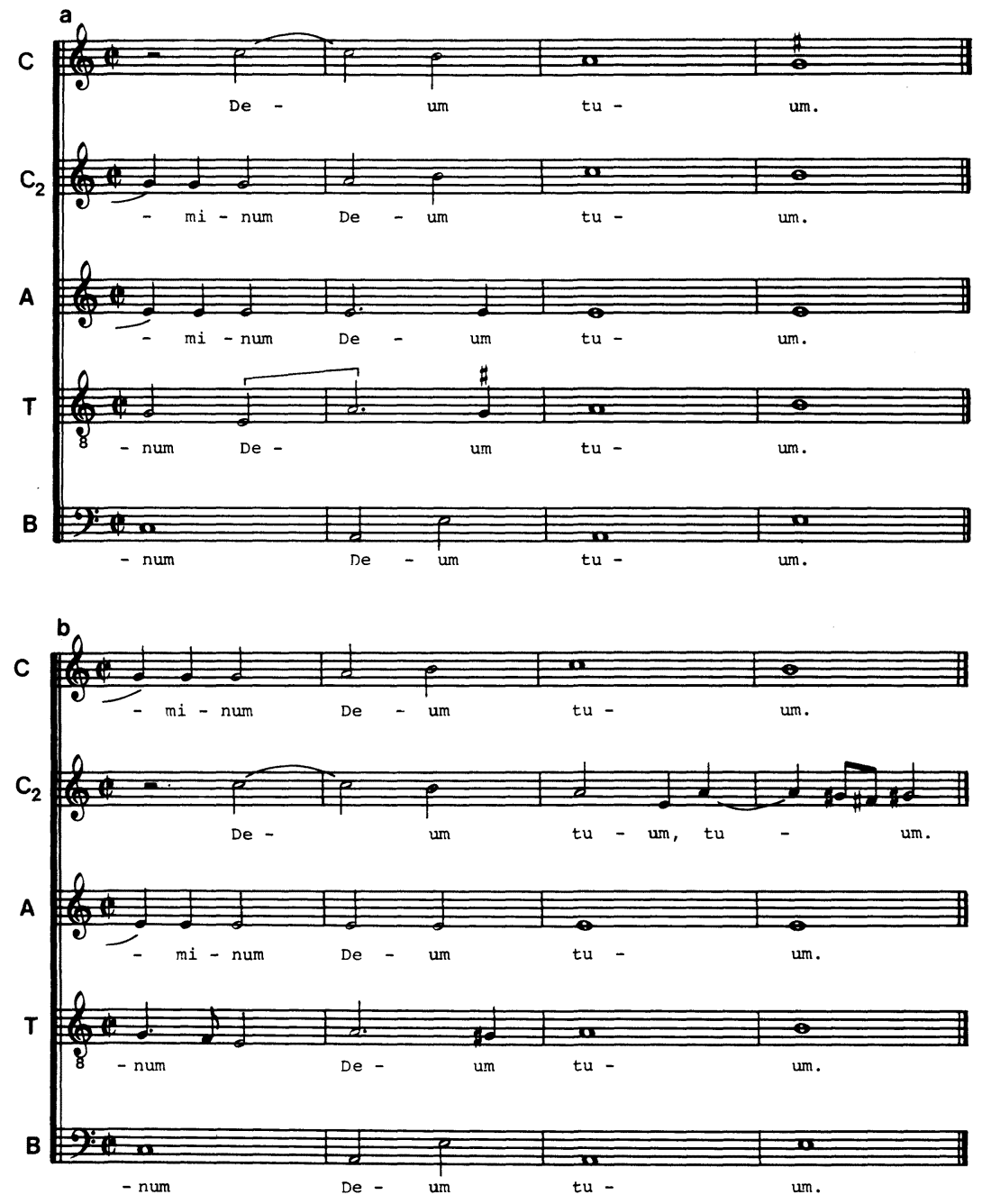

Extract from the conclusio a 5 from Lectio II of the Saturday Lamentations. (a) Cappella Sistina Ms. 186, (b) Officium Hebdomadae Sanctae. Example 7 
There are a number of instances of the ornamented 4-3 suspension, which is often thought of as characteristic of Victoria's "early" style, in the Missa Salve regina of 1592 in passages that bear no relation to the 1576 model. And the presence of an added anticipation in measure fifty-five of the cantus in the 1585 edition of the motet "Vere languores," as well as the omission of a lower neighbor ornamenting tone in measure twenty of the altus secundus in the later editions of the motet "Benedicite sit" also makes it difficult to attach any import, stylistic or otherwise, to the changes Victoria made in this very important area during the course of his compositional career.

\section{Sound}

That Victoria found it expedient to change the position of the voices on the page for many of the pieces in his Lamentations when he came to printing them is another very interesting example of his second thoughts. Generally speaking, the changes Victoria made in the format do not materially affect the sound of the piece. There is, however, one notable exception. In the conclusio for Lectio III of Holy Saturday, the last piece in the Lamentations and the only eight voiced piece in the entire work - the big finale, as it were the different format does indeed alter the aural impact, especially when it is performed from the choirbook itself. In Cappella Sistina Ms 186 the $\mathrm{C} 1, \mathrm{C} 2, \mathrm{~T} 1$, and $\mathrm{T} 2$ are on the left side of the opening and the $A 1, A 2, B 1$, and $B 2$ are on the right. In the Officium Hebdomadae Sanctae the C1, A1, T1, and B1 are on the left side and the $\mathrm{C} 2, \mathrm{~A} 2, \mathrm{~T} 2$, and $\mathrm{B} 2$ are on the right side. In effect, this new format places in relief the antiphonal nature of the initial measures of this composition by dividing the ensemble by performing group, that is, into two equal choirs, rather than by range. This change, of course, reflects the displacement of the high-low division common in the early part of the sixteenth century by the equal choir division popular with the Venetian composers of the last half of the century.

Related to the change in format discussed above are the two alterations Victoria made in the 1585 edition of his double choir Psalm motet "Super flumina," given in Example 8 and 9 respectively. In the original version (1576), the two phrases of the first passage are discrete units. But in the revision the two phrases overlap. In the second passage, Victoria has not only given the music for the repeat of the text to the first choir, thus capitalizing on the performing resources at his disposal, but has also rewritten 
it so that it cadences on the dominant rather than on the tonic, and he has dovetailed the two statements. Victoria's revision of his Psalm motet "Nisi Dominus" (1576) is in a similar vein. In the 1583 edition, a statement of the opening three measures of the second chorus has been added to the part for the first chorus, thereby increasing by one the number of antiphonal exchanges.

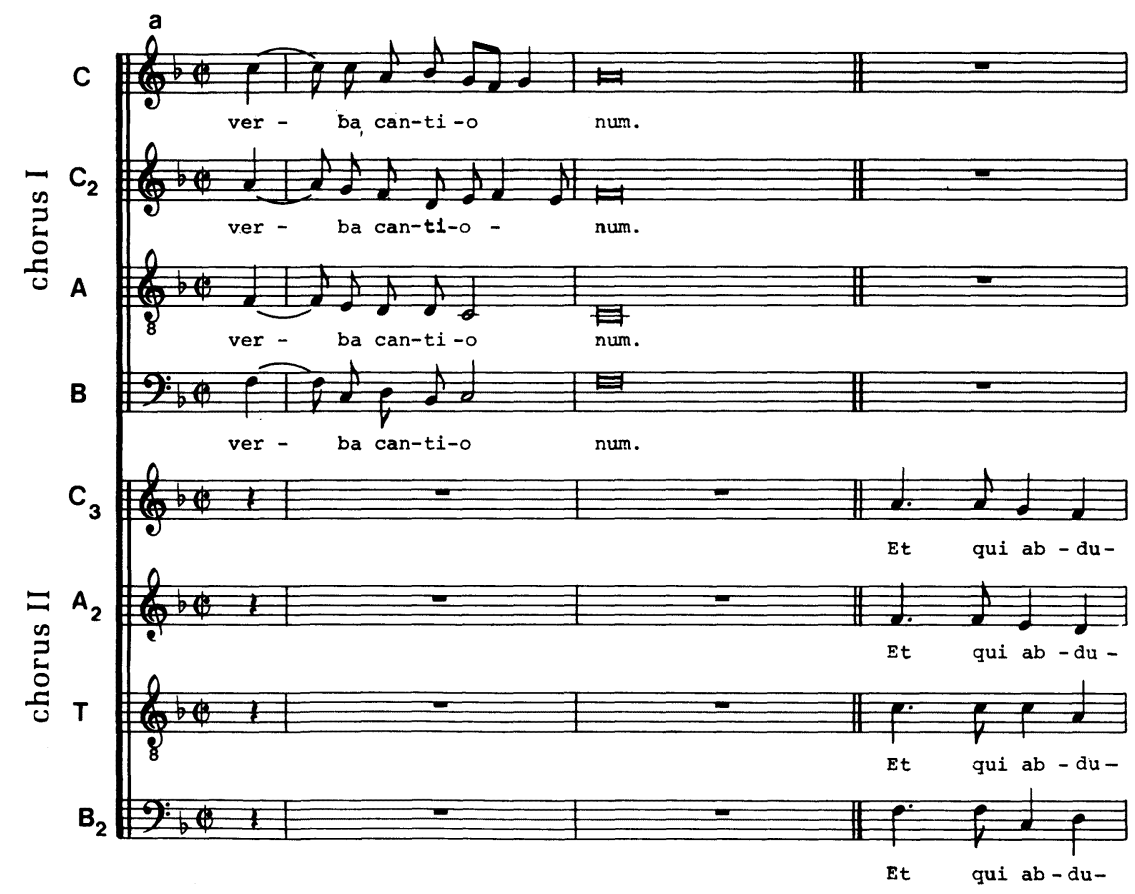




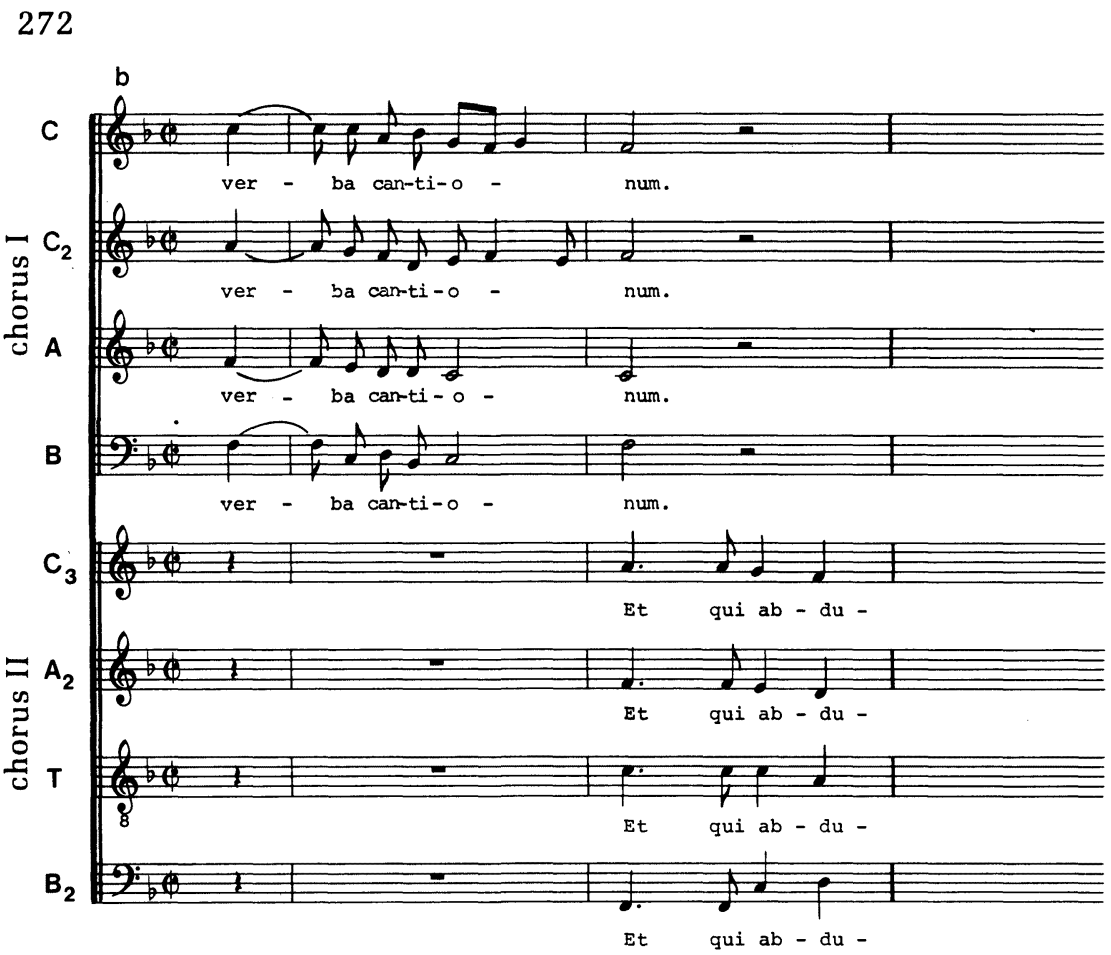

Extract from the motet "Super flumina."

(a) 1576 version, (b) 1585 version. Example 8 


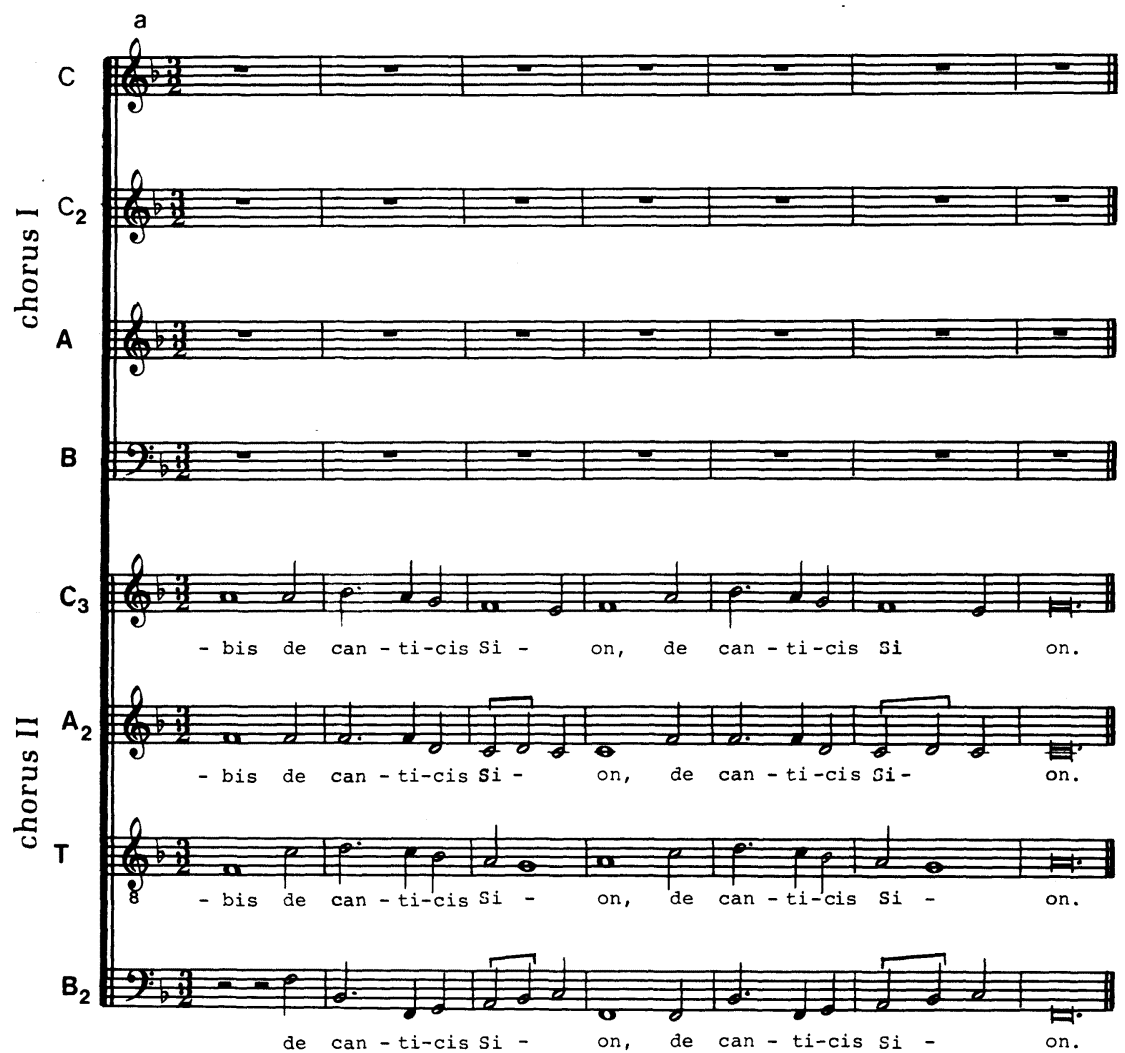




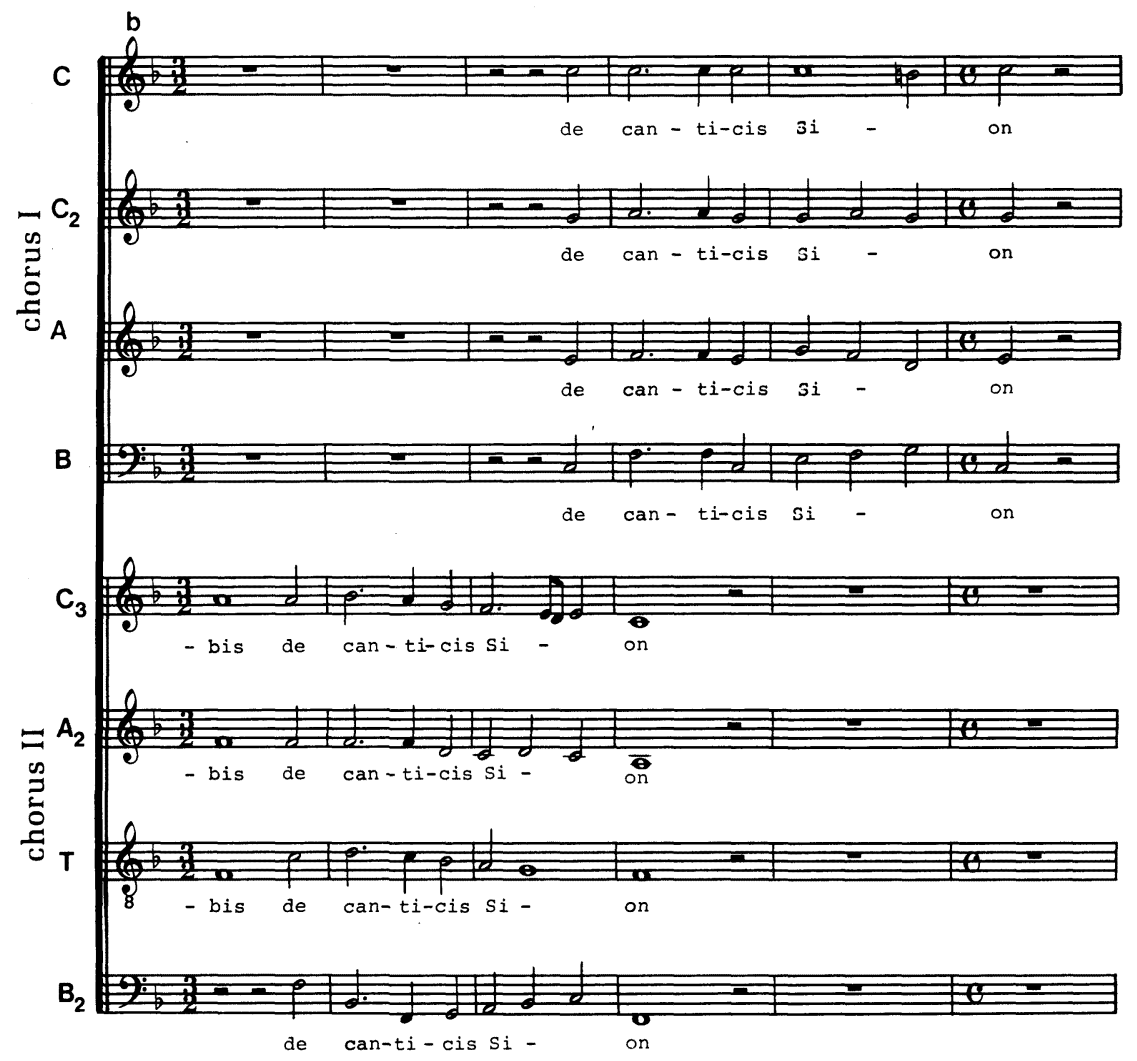

Extract from the motet "Super flumina."

(a) 1576 version, (b) 1585 version.

Example 9

The most significant of the revisions found in the very important miscellany titled Missae, Magnificat, Motecta, Psalmi et quam plurima for 8, 9, and 12 voices, published in Madrid in 1600 , is the addition of a part for the organ to several compositions that had appeared in earlier publications without any indication of instrumental participation. The fifteen works affected include the "Ave Maria," a 8 from the 1572 book of motets, the "Salve regina" a8 and "Super flumina," both from the 1576 collection, as well as those movements of the 1576 Magnificat Primi Toni and the 1581 Magnificat Sexti Toni that were transferred intact to the 1600 version of these two works. This action by Victoria seems to indicate a substantive change in his thinking, because in so doing 
he brought these works into line with the style of those that appeared for the first time in this publication. Moreover, we can see that Victoria recognized that the use of instruments was an important feature of the emerging Baroque style.

It is obvious that the evidence presented thus far is somewhat contradictory in regard to the basic question: "Why?" On the one hand, it can be seen that Victoria made a few changes that clearly would indicate his desire to update his earlier work so that it could reflect his then current style. On the other hand, the discussion shows that he continued to use such details as the escape note and the quasi fifteenth-century cadential figure after completing his sojourn in Rome. It would therefore appear that the changes he made in the 1580s, in these areas at least, were probably made not for stylistic reasons, but for some other reason, possibly political, that is, to please a patron or a different audience. For the rest, neither of these reasons offers a satisfactory solution and we are left with only guesses.

\section{Musica ficta}

The aggregate of his changes in the area of ornamentation notwithstanding, it was in the indication of accidentals that Victoria made the greatest number of alterations over the years. He was, in fact, so unsparing and meticulous in his indication of the accidentals he wanted to be sung, and so far ahead of his time in this regard, that when his motet "O magnum mysterium" was anthologized by Donfried in 1622 with an added figured bass, the editor did not have to add a single accidental to make it comprehensible to singers unfamiliar with the style of the late sixteenth century (see Stevenson 1961: 449). It is no wonder, then, that the changes of this kind which one finds in the various editions of Victoria's works have already exercised a number of scholars. Samuel Rubio's study of these alterations in Victoria's motets is the most important of these (see Rubio 1950 and Stevenson 1961: 442-45). Although its main thrust is bibliographical, Rubio's study seems to confirm the Romanization hypothesis put forward earlier by Casimiri in respect to Victoria's works (see Casimiri 1934 and Stevenson 1961: 445) and already mentioned in this study in another context. For example, the Csharp in measures twenty-two and twenty-six of "Vere languores" is changed to a C-natural only in the 1585 Roman imprint of this motet, the Officium Hebdomadae Sanctae. Similarly, the F-sharp in measures fifteen and forty-four of the motet "Pueri Hebraeorum" is an F-natural in the two Roman editions of 1583 and 1585. 
Changes of this type made by Victoria in the 1600 edition of the "Et misericordia" and "Suscepit Israel" verses from the Magnificat Primi Toni of 1576, though somewhat different, do not alter this hypothesis. In both of these verses, the 1600 version prefers a B-flat on two occasions where the earlier one indicated a B-natural (measure thirty-four of the cantus secundus of the "Et misericordia" verse and measure twenty-one of the tenor of the "Suscepit Israel" verse). Whether these changes are to be construed as manifestations of Victoria's conservatism, or as late examples of the Romanization hypothesis depends on the point of view of the observer. Moreover, in the 1600 version of the "Et misericordia" verse, Victoria explicitly indicates that the penultimate note of the cantus should be an E-flat where in the earlier version of this Magnificat he had left this detail to the discretion of the singer - although no singer would ever have sung an E-natural at this point given the melodic and harmonic surroundings. Finally, attention is drawn to two occasions in the 1600 edition of the "Suscepit Israel" verse of this Magnificat where Victoria adds a sharp to an F (altus 2,2 and cantus 5,4 ). In so far as these additions only make explicit the assumed unwrittent performance practice implicit in the rules of musica ficta, the stylistic implications to be drawn from them are minimal, if not nonexistent. Certainly, there is no direct Roman cause for any of the alterations Victoria made in this Magnificat because the first version was published in Venice and the second in Madrid. Thus, whether Victoria changed these accidentals and similar ones in other pieces for stylistic reasons or for some other as yet unidentified reason is a question that cannot be resolved unless we allow for the possibility that he made them for a variety of different reasons as opposed to a single overriding one. For instance, they might have been made in one case because he really wanted it that way at that moment, in another because he was deferring to the taste of a particular group - for example, the musical establishment in Rome - in another because he was under pressure from the printer to do so, and in yet another because he was simply trying to clarify the melodic motion.

\section{Texture}

When one considers the change made in passages in the Lamentations such as the one given in Example 10, one is inclined to conclude that between about 1565 to 1585 Victoria's style did, indeed, undergo a substantive change and became less imitative 
and more homorhythmic. Such a conclusion, however, would be open to considerable dispute because not only does Victoria pursue the opposite course on occasion, as is shown in Example 11, but, as a glance at the passage given in Example 12 will demonstrate, he was also capable of turning a simple two voice imitative point into a four voice contrapuntal tour de force in revising this work for publication in 1585 . It does not take a genius to realize that the varied nature of the changes in texture one finds in Victoria's revisions precludes any simple stylistic reason for their existence.
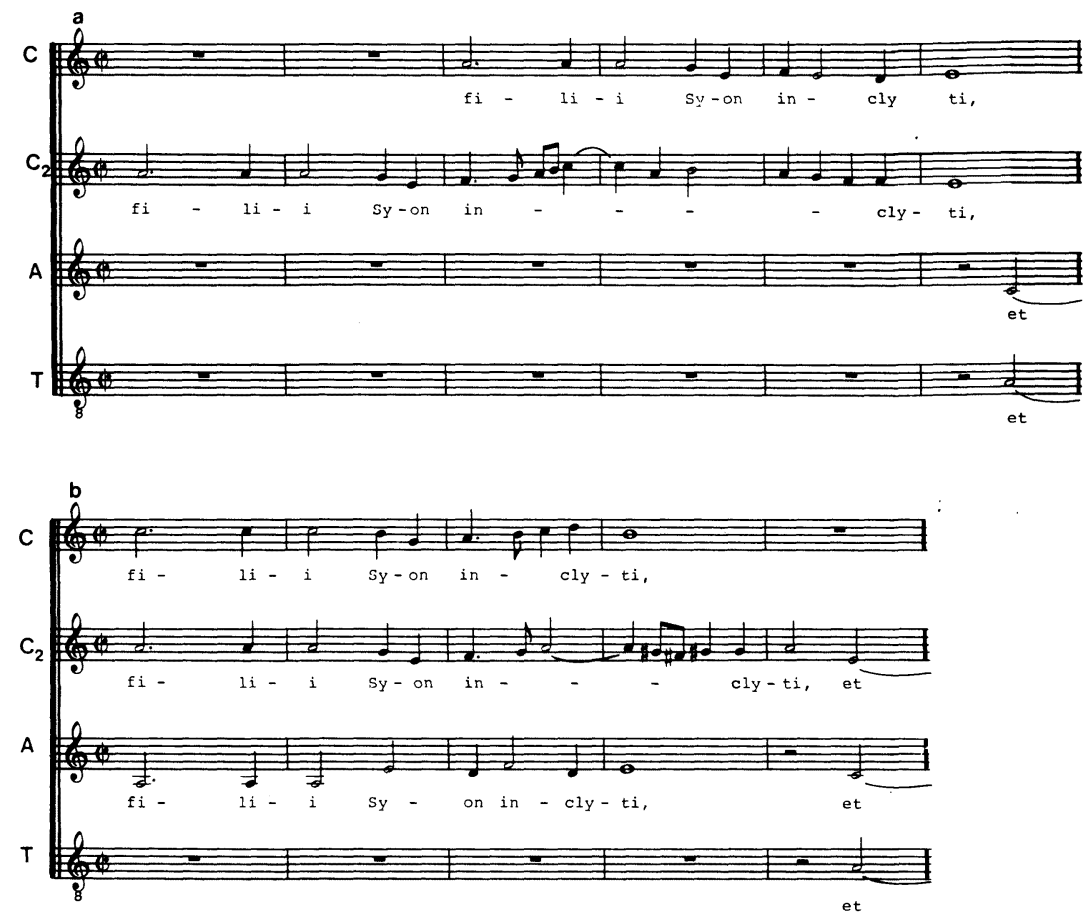

Extract from Lectio II of the Saturday Lamentations.

(a) Cappella Sistina Ms. 186, (b) Officium Hebdomadae Sanctae. Example 10 
a

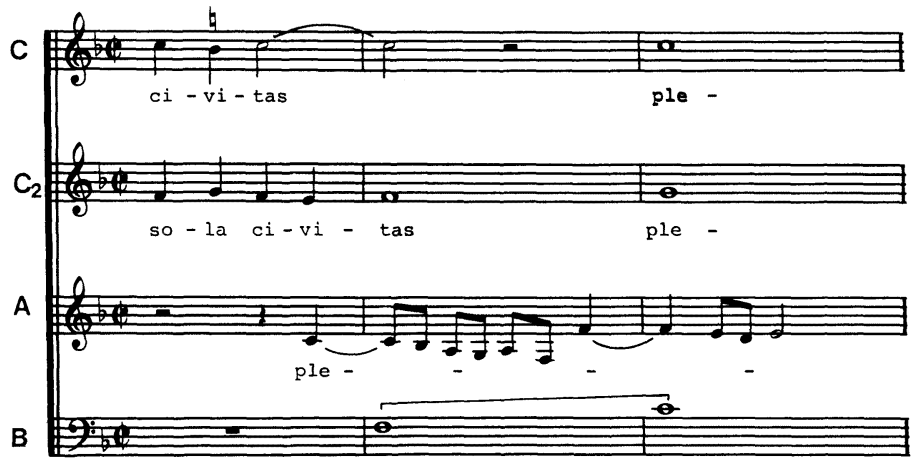

ple -

b

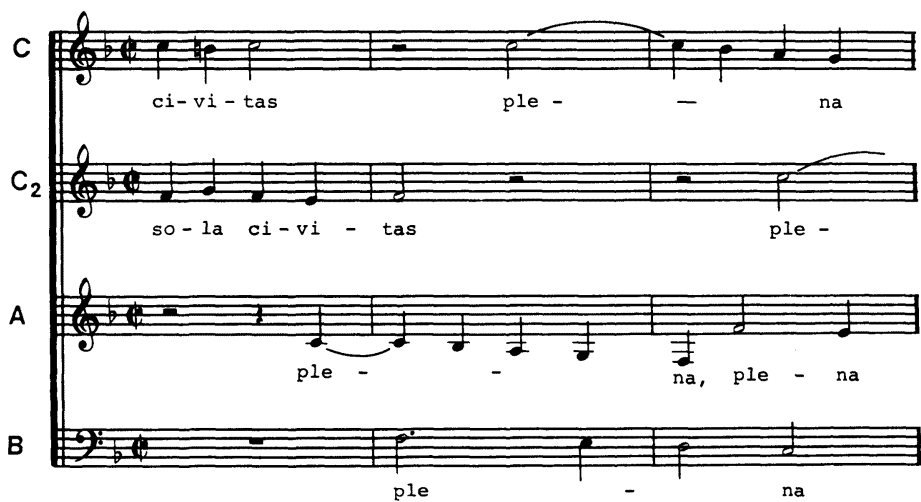

Extract from Lectio I of the Thursday Lamentations. (a) Cappella Sistina Ms. 186, (b) Officium Hebdomadae Sanctae. Example 11 

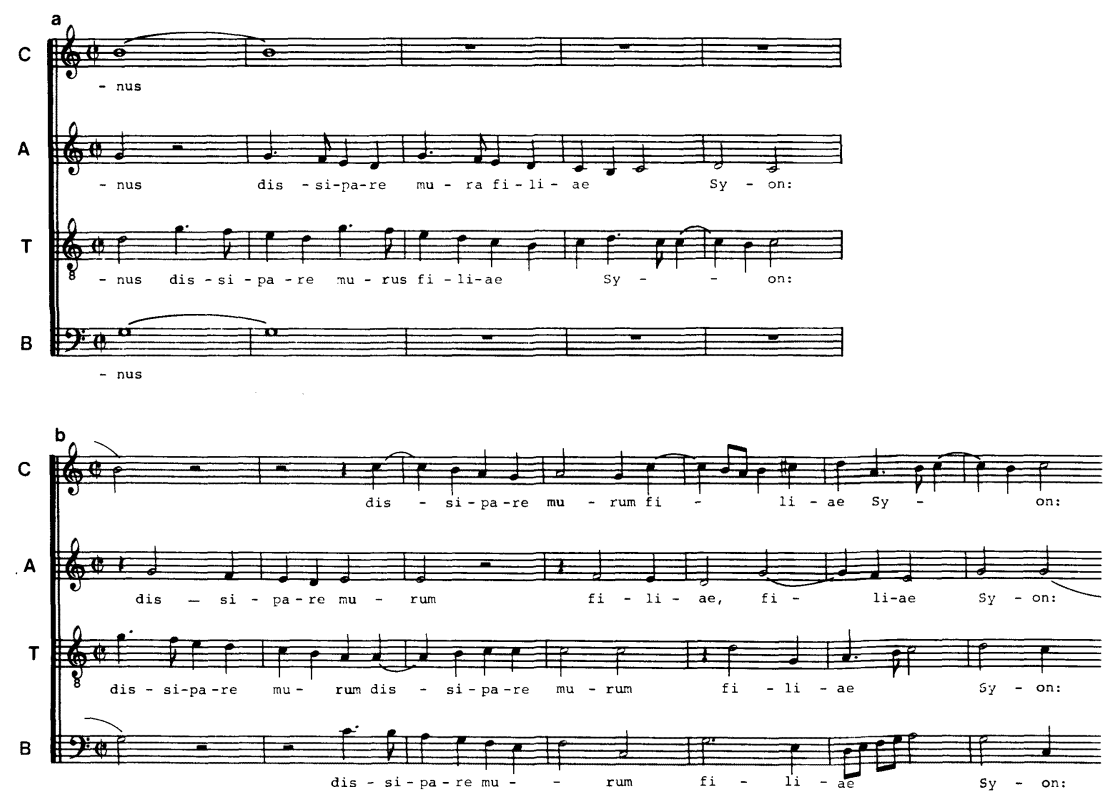

Extract from Lectio I of the Friday Lamentations.

(a) Cappella Sistina Ms. 186, (b) Officium Hebdomadae Sanctae.

Example 12

\section{Harmony}

Nor was the parameter of harmony sacrosanct. Often, the changes Victoria made in this area either clarify or strengthen the harmonic progression, as in the passage given in Example 13 where the progression i-vii ${ }_{6}^{\circ}$ of flat VII-flat VII-vii ${ }_{6}$ of iv-iv-i-V-i has much more more direction and purpose than the earlier $\mathrm{i}-\mathrm{vii}^{\circ}{ }_{6}$ of flat VII-III-iv $\mathrm{v}_{6}-\mathrm{V}$ progression.

But, as in the other areas delineated above, there are also harmonic changes in which the reason for the alteration is not readily discernible, and certainly does not unequivocally support the view that Victoria made these changes in order to render the tonality of his music clearer, and hence to update his works. For example, one can only be baffled by the change from an A minor first inversion chord to a $C$ major chord in root position, given in Example 14. Surely, no stylistic change can be inferred from such an alteration. 
280
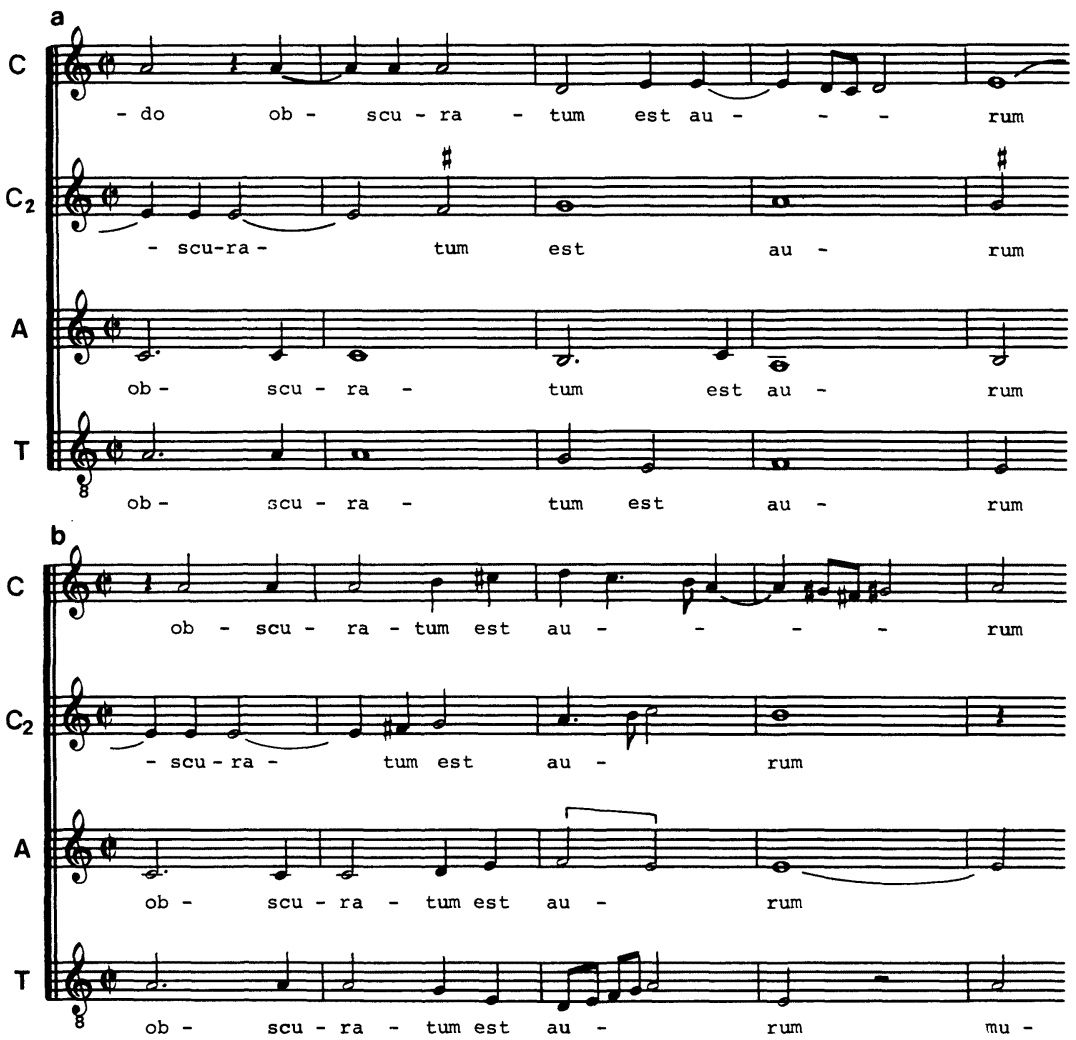

Extract from Lectio II of the Saturday Lamentations.

(a) Cappella Sistina Ms. 186, (b) Officium Hebdomadae Sanctae.

Example 13 

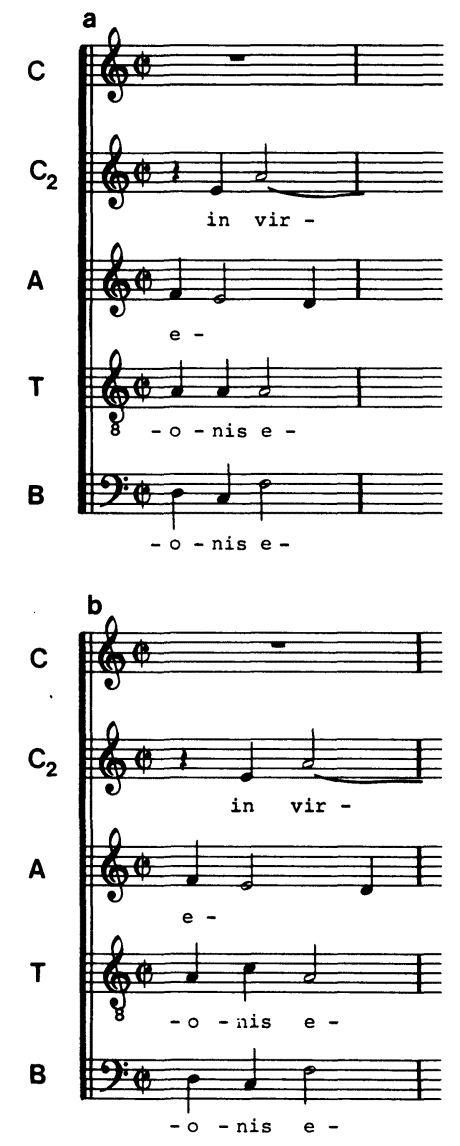

Extract from Lectio III of the Saturday Lamentations.

(a) Cappella Sistina Ms. 186, (b) Officium Hebdomadae Sanctae.

Example 14

\section{Cadence structure}

When Victoria prepared his Lamentations for print, he seems also to have had second thoughts about some of the cadences in the earlier version, for we find that in the Officium Hebdomadae Sanctae a total of ten of them have been changed. It is true that the number of altered cadences is not very large. And yet, the changes are often substantive enough to affect the character of the entire piece.

A survey of his cadential changes shows that on two occasions an authentic cadence replaces a vii ${ }_{6}$-I progression - 
the so-called Dorian cadence - and on two others he substitutes an authentic cadence for a Phrygian one. On three occasions he also saw fit to omit the plagal extension of an authentic cadence and on two others to drop the plagal extension of a Phrygian cadence. Incidentally, the dropping of the plagal extension of an authentic cadence is also one of the changes Victoria made in his 1585 revision of the motet "Doctor bonus," but which he later (1603) retracted. In the tenth cadential change referred to above, Victoria took the extraordinary step of replacing an authentic cadence with plagal extension with a simple plagal cadence.

On the basis of these cadential changes, it would appear that the use of the authentic cadence was more characteristic of Victoria's style around 1585 than it had been around 1565 and that his thinking in general had become more tonal. But when Victoria's setting of the Lamentations as a whole is examined, such a conclusion cannot be sustained. Not only did Victoria retain several $\mathrm{vii}_{6}^{\circ}$-I cadences in the version in the Officium Hebdomadae Sanctae, but he also kept several Phrygian cadences as well as a number of plagal extensions. Moreover, he also employed these ostensibly archaic cadential formulas, especially the Phrygian cadence and the plagal extension of an authentic cadence, in those sections of the Lamentations that are not found in Cappella Sistina Ms. 186 and which, therefore, we must assume were written specifically for the Officium Hebdomadae Sanctae version - presumably just prior to its publication, that is, about 1584-85.

\section{Conclusion}

What, if anything, has this examination of Victoria's second thoughts shown? First, I believe it shows that, contrary to expectations, Victoria did not revise his compositions only or even primarily to bring them into line with his developing style. Of course, there are cases where this appears to have been his intention, but these are far outweighed both in number and substance by those cases which contradict any such intent. Second, it shows that Victoria was a slave neither to his craft nor to the fashions of a particular place. The lack of consistency in nearly every one of the areas examined gives the lie to such conclusions.

Finally, this examination shows that even though his compositional technique had improved and even though his way of doing certain things had changed markedly over the years, 
Victoria was not one to unilaterally apply the new manner to his creations, either old ones or new. On the contrary, even as a mature composer, he dealt with each musical situation on its own merits and left a particular passage as it stood or changed it in the way that he believed to be most suitable at that particular time. Because of this apparent lack of direction, an unsympathetic observer might be disposed to conclude that Victoria was an inveterate tinkerer, or worse, someone who did not have the strength of his convictions and, like Bruckner, accepted advice from everyone regardless of their qualifications to give it. It is possible, also, that he was merely a crass commercialist, changing his creations at every opportunity so that the musical public would have to buy a copy of the latest publication in order to be au courant. A more benevolent student of Victoria's revisions, however, would be inclined to interpret his changes as indicating that appropriateness to the given musical situation and the integrity and immediacy of expression were more important to him than uniformity of language. It is this latter view which this student of Victoria's music, at least, is inclined to accept.

\section{REFERENCES}

CASIMIRI, R.

1934: "Il Vittoria," Note d'Archivio, XI/2 (April-June), 133-34. CRAMER, E.

1982: Officium Hebdomadae Sanctae, Tomás Luis de Victoria. Vol. I: Introduction. Henryville-Ottawa-Binningen: The Institute of Mediaeval Music.

JEPPESEN, K.

1970: The Style of Palestrina and the Dissonance (1946). New York: Dover.

KRIEWALD, J.A.

1968: "The Contrapuntal and Harmonic Style of Tomás Luis de Victoria." Ph.D. dissertation, University of Wisconsin.

MARSHALL, H.L.

1970: The Four-voice Motets of Thomas Crecquillon. Vol. I. Brooklyn: The Institute of Mediaeval Music.

RUBIO, S.

1950: "Historia de las reediciones de los Motetes de T.L. Victoria," La Ciudad de Dios, CLXII/2 (May-August), 313-51. STEVENSON, $R$.

1961: Spanish Cathedral Music in the Golden Age. Berkeley: University of California Press. 